\title{
CORRIGENDUM
}

\section{Pharmacological enhancement of mGlu5 receptors rescues behavioral deficits in SHANK3 knock-out mice}

C Vicidomini, L Ponzoni, D Lim, MJ Schmeisser, D Reim, N Morello, D Orellana, A Tozzi, V Durante, P Scalmani, M Mantegazza, AA Genazzani, M Giustetto, M Sala, P Calabresi, TM Boeckers, C Sala and C Verpelli

Molecular Psychiatry (2017) 22, 784; doi:10.1038/mp.2016.70; published online 26 April 2016

Correction to: Molecular Psychiatry (2017) 22, 689-702; doi:10.1038/mp.2016.30; published online 29 March 2016

Following publication of this paper, the authors noticed that the affiliations for M Giustetto, C Vicidomini, C Sala and C Verpelli were incorrect. The correct affiliations appear below:

C Vicidomini ${ }^{1,2}$, L Ponzoni, D Lim, MJ Schmeisser, D Reim, N Morello, D Orellana, A Tozzi, V Durante, P Scalmani, M
Mantegazza, AA Genazzani, M Giustetto ${ }^{3}$, M Sala, P Calabresi, TM Boeckers, C Sala ${ }^{1,2}$ and C Verpelli ${ }^{1,2}$

${ }^{1}$ CNR Neuroscience Institute, Milan, Italy;

${ }^{2}$ BIOMETRA University of Milan, Milan, Italy;

${ }^{3}$ Department of Neuroscience, University of Turin, Turin, Italy; 